YNour:3, Volume:3, Number:5 / Yul:3, Cilt:3, Sayt:5 / 2019

DOI Number: 10.30520/tjsosci.522048

\title{
WHY IT IS TOO DIFFICULT TO DOWN ASSAD?: THE MURPHY LAWS OF INTERNATIONAL RELATIONS ${ }^{1}$
}

\author{
Yiğit Anıl GÜZELIPEK ${ }^{2}$
}

\begin{abstract}
In the modern history, Arab Spring was one of the most important merciless challenge to military dictatorships all around the Middle East. All the dictators lost their rotten thrones sooner or later except Bashar el-Assad. There are many political or strategic explanations regarding how Assad still partly protects his power and still represents Syria in the position of presidency. On the other hand, sometimes "perfectly" designed international politics fall behind while interpreting the "destined" side of international relations. In other words, sometimes "expect the unexpected" which is the famous formula of Murphy Laws determine the critical developments in international relations. This paper aims to investigate the Assad's survival based on the Murphy Laws which is considered as one of the natural extension of post-positivist theory in international relations. In order to support the arguments of this paper, other historical developments are also adapted to the study.
\end{abstract}

Key Words: Arab Spring, Assad, Post-Positivism, Murphy Laws, International Relations

\section{1-Literature Review}

The correlation between Murphy Laws and politics seems quite unfamiliar for the international relations discipline. Regarding Murphy Laws, in this study it is found that most of the academic studies regarding the Murphy Laws are conducted in the frame of engineering and other life sciences including mathematics. Despite of the fact that Murphy Laws has become identical with famous American engineer Edward Murphy, many decades before him some academic writings/ideas anticipate the "unnamed" main arguments of Edward Murphy. In this sense, mathematician Augustus de Morgan should be considered as one of the primary names who creates a correlation between mathematics, religion and politics. (Phillips: 2004, 106). It can be argued that since Morgan, theological explanations -even for the life scienceshas become the subject of scientific researches. In parallel to Morgan, in 1878, Alfred Holt's book Review of the Progress of Steam Shipping During the Last Quarter of a Century exerts the unexpected mechanic failures in the sense of "expecting the unexpected" motto of Edward Murphy (Holt: 1878).

On the other hand, Arhur Bloch's famous book Murphy Law and Other Reasons Why Things Go Wrong can be considered as one of the most important writing regarding the Murphy Laws (Bloch, 1978). Beside Bloch's explanations regarding the failure of "things", in 1997, Robert A. J. Matthews radically names the aforementioned scientists/writer theories as "the

\footnotetext{
${ }^{1}$ This paper is verbally presented in the 1 . International Congress on People, Power\&Politics in Kırşehir/Turkey on the date of 20 October 2018

${ }^{2}$ Dr. Öğr. Üyesi, Karamanoğlu Mehmetbey Üniversitesi, Siyaset Bilimi ve Uluslararası İlişkiler Bölümü, guzelipek@gmail.com
} 
universe is against you" by using a metaphysical approach (Matthews: 1997, 88). Thus far, even Murphy Laws are adapted to science mostly by the life scientists, Ralph J. Murphy perfectly adapts the Murphy Laws to arts by his book Murphy's Laws of Song Writing: The Book by arguing writing a good song doesn't make someone a good song writer (Murphy: 2011).

On the other hand, despite of these arguments regarding the adaptability of Murphy Laws to different science fields, needless to mentioned that there are also strong criticisms regarding the validity of Murphy Laws. In his paperback, Chatterjee strongly contradicts with the arguments of Murphy Laws by using mathematical proofs. (Chatterjee: 2015) In this context, not only in the life sciences but also in the international relations discipline, there are also very strong criticisms to states'/systems' unpredictability question. For example, in this famous article Reckless States and Realism John J. Mearsheimer objects the arguments of Kenneth Waltz regarding the states' predictability question (Mearsheimer: 2009). On the other hand, unlike this study, the (un)predictability of states and other international actors are not considered in the context of "Murphy Laws of International Relations" perception. Because of this reason, the literature review part is cramped by only the academic literature of Murphy Laws.

\section{2-Introduction}

Since almost a decade, Middle East has been the major study field of many academic researches due to the tremendous instability in the region. In the very beginning of the crises, while most of the analyses were occupied by the "will these dictators fall?" question; recently, most of the researches focus on the second and third party's calculations towards the area and reconstructing process in various Arab countries. On the other hand, Syrian Crises has challenged to this ex parte perusal. Inasmuch as, still the Syrian Crises offers availability to both of these two questions. Needless to mention that Assad's survival stems from many political calculations and strategies. In the first place, Moscow's strategic nostalgia towards Syria (Allison:2013, 795) and his intense engagement to crises might be considered as the major reason of this fact. Moreover, beyond a strategic nostalgia this engagement can be considered in the frame of a strategic obligation for Moscow in order to balance the US existence in Middle East. On the other hand, in accordance with Assad, while Saddam Hussein was in the favor of Ba'thism rather than Islamism (Helfont: 2014, 357), Moscow didn't take any serious action in 2003 to protect his former allied. By using a pragmatist approach it might be argued that Moscow didn't need Saddam anymore or that time Russia's power capacity was not sufficient to resist the USA. On the other hand, simultaneous developments which took place in the frame of Syrian Crises, such as in Gaddafi's Libya which was also a socialist regime, didn't attract the Moscow's protection. In the light of these information, it might be argued that Ba'thism can't be considered as a "magic lamb" for Russia to protect the regimes which are in the target of both (inter)national opponents. Without any doubt, USA and Russia aren't the only actors that involved to Syrian Crises. According to Swaine, China's Assad-oriented position in Syrian Crises stems from two major reasons. In the first place, Beijing is in opposition to any outsider intervention to Syria, particularly in the leadership of NATO, and due to this reason China primarily supervises his economic interests in the Middle East. (Swaine:2012,2). On the other hand, this perspective falls short to explain neither the enormous economic losses of China since the Arab Spring began nor the NATO intervention which took place to Libya. Except for this, regarding the parallel approach of Tehran, it is believed that in spite of being two different regimes, due to security reasons, particularly resistance to Israel, Iran and Syria regimes have to cooperate (Mohammed:2011,67); on the other hand, it is also very difficult to explain why the "same" 
Tehran left Bahrain to its "destiny" while calling the country as his "own province" (Khalifa:2014,5).Besides the strategic arguments behind the Assad's survival, some approaches focus on the human factor which mostly offer sociological explanation regarding the Syrian Crises.

The first argument focuses on the on the Syrian people's "sufficient" support to Assad which still keeps him in power. In this context, a critical question emerges: "Was the situation too different in other Middle Eastern countries that affected by the Arab Spring?" Unquestionably, the answer of this question is no. Just because, the military dictatorships that came to power in various Middle Eastern countries by the 1950's and 1960's already had their similar social contracts with their citizens by providing them low cost or free basic services, setting up a large number of public sectors factories and companies and persuading and consolidating them around the Israel threat (Winckler:2013,68).Regarding the human factor explanations behind the Assad's survival, the focus to his military knowledge and skills might be the most ridiculous one since the overturned Gaddafi, Mubarak or Ben Ali were also coming from successful military careers. So, why Assad didn't fall in contrast to the wide expectations?

In the first place, it has to be mentioned that this paper primarily accepts the reason of Assad's survival based on the strategic and political calculations. In other words, metaphysics or similar theological approaches can't explain Assad's survival from the Arab Spring only by themselves. On the other hand, this study argues that Assad survival also can't be analyzed only based on the strategic facts which are basically counted in the previous paragraphs. In this context, it is believed that post-positivist theory ${ }^{3}$ of international relations shall be very explanatory for this study.

Except the introduction, literature review and conclusion parts, this study is constructed into two main chapters. In the first chapter, positivism and post-positivist debate shall be briefly explained and in the second chapter, Murphy Laws of international relations shall be investigated by two transdisciplinary terms call heterarchy and entropy which are considered as the key standpoints of Assad's survival.

\section{3-Positivism or Post-Positivism?:The Both}

Apart from its scientificity question, the very complex nature of international relations forces the academicians to create theories in order to give the meaning of international relations and explain the international actors' behaviors. In spite of all these mental efforts, still it is not possible to explain the nature of international relations with theories. On the other hand, it seems also impossible to explain the nature of international relations without theories. Especially since Robert Cox stated in famous article Social Forces, States and World Orders: Beyond International Relations Theory that international relations theories always serve someone's interests (Cox: 1981, 129), even the scientificity of international relations theories had become suspicious though they were created in order to "solve" the scientificity question of international relations as a discipline. On the other hand, in spite of Cox's harsh criticism to international relations theories, still the three great debates construct the "vertebral column" of international relations.

Realism and idealism debate which can be considered as a "half philosophical" debate is accepted as the first great debate of international relations. Moreover, the very first debate of

\footnotetext{
${ }^{3}$ Murphy Laws which constructs the "vertebral column" of this paper is reproduced by the author in the context of positivism and post-positivism debate.
} 
international relations gains its importance for being the "existence reason" of other international relations theories (Çalış and Özlük: 2007, 231). On the other hand, within the modern nature of international relations, it is impossible to explain the discipline only by using the anarchy and power maximization "clichés". In the second place, the very well known "key words" of the first debate such as "power" draw a very relative profile. Because of this reason, during the Cold War era, the second great debate of international relations call traditionalism and behavioralism debate took place. Needless to mention that, traditionalism and behavioralism debate was also too far from being a philosophical debate due to the arguments of both parties were constructed in the sense of methodology of international relations and international relations' potential "harmony" with the methodology of life sciences. Hither to as Kenneth Waltz and other positivists state, the dynamics of international system limits the movement area of units and this generally makes the international actors' behaviors and their outcomes predictable (Rose: 1998: 145) On the other hand, despite of the fact that Waltz carefully produces his argument by using the word of "generally", the unpredictability of international relations definitely challenges the major arguments of positivist approaches within the discipline.

In this context, the third great debate in the discipline call positivism and post-positivism debate can be considered as a "memorization disrupting" approach to the source of knowledge and the nature of international relations. In the first place, it has to mentioned that post-positivist approach in international relations accepts the examination of social systems but it rejects the examination of social system based on the methodology of life sciences by using the epistemological means (Yalvaç: 2010, 5). In other words, post-positivism produces a critical approach to the knowledge and the nature of international system. In this context, it can be argued that by the "revolutionary" influence of post-positivism in international relations, the discipline relatively lost its concerns in the sense of finding "objective" data and common "rules" (Yetim and Erdağ: 2018, 80). Quite the contrary, after its foundation in the first quarter of 20.century, during the 1990's, for the first time international relations discipline "accepted" the existence of relativity and unpredictability. Obviously, the "transformation" of the discipline entailed some major changes regarding the perception of international relations. In the first place, regarding the examination of international developments, academics has started to focus on the "how" question instead of insisting on the "why" question. In the second place, "catching" the trends of international relations has become more important instead of producing common rules for the discipline. Lastly, the natural result of these changes was accepting the unpredictability of international relations which means any actor of the system can do anything without considering its capacity. The following chapter will locate the major arguments of positivism and post-positivism debate to the Murphy Laws.

\section{4-The Footprints of Murphy Laws in International Relations}

Nine days you go out with your umbrella; but it doesn't rain. Only one day you forget your
umbrella and the heavy rain catches you...
Your drop your shopping bag and most probably you dropped the one with full of eggs...
Left to themselves, things tend to from bad to worse...(Anonymous)

In fact, these amusing but actual situations encounter to almost anybody during the trot of daily life. When American engineer Edward Murphy had started to investigate the fall of systems and common error codes; he had opened a new era with full of complexities and 
opacities entailed to this question: "Why should we always expect the unexpected?" At the first sight, it is too difficult the give the right answers of Murphy's findings, due the question involves many disciplines especially theology and philosophy. On the other hand, it is a fact that the term of "hidden flows" (Spark:2011, 7) affect the international system by creating huge black spaces and major error codes within the system. At first sight, Murphy Laws might be considered in the frame of political realism due this theory focus on the chaotic environment of international relations. On the other hand, because of the reason that realism is based on rationalism and political hierarchy (Donnelly: 2009, 50-51), the theory comes up short to explain the improbability and the question of "why systems burn themselves out?" In other words, the international theories can't give the answers of these developments which served us a totally different international relations profile:

In 1914, due to the rising nationalism within the international system especially in Balkans, the most unwanted thing could be an assassination which could cause a world war. Quite the contrary, when Archduke Franz Ferdinand's driver made an unexpected wrong turn (Ullman:2014,1), his official car had become an open target for Gavrilo Princip and the assassination which changed the whole international system had actualized. Through the recent history, similar developments emerged again in Balkans on the case of Yugoslavia. After the death of Josip Broz Tito, in the sense of rational expectations, the worst choice could be Slobodan Milosevic who was known by his nationalistic fanaticism. On the other hand, till the very beginning of 2000's when he was down by the international community, he bolstered his legitimacy (Schulte:2015, 46) with "democratic means" which finally led the collapse of Yugoslavia. Exactly in the same years, without any doubt, USA was the less expected country to face with a terrorist attack; but beside it came true, the consequences of 9/11 on US foreign policy has started a new era in international system which is keeps its validity even for today. There is no need to mention the historical failure of USA in Vietnam in contrast to the expectations or people's sarcastic attitude for the power capacity of Prussia in the very beginning (Treitschke:1914, 101).

According to many people, these incidents might be considered as a failure of human factor; on the other hand, American and French Revolutions set a remarkable sample of hidden flows which caused the failure of a complete system within the short and midterm of the movements. In the first place, it has to be mentioned that both of these two revolutions can be considered in the frame of the Arab Spring due to their emergence which stems for the liberalistic tendencies. On the other hand, the short and midterm consequences of these movements were total disappointments especially for the people/classes who were the initiatives. Besides the unanswerable side of American Revolution in the respect of whether Americans were right or wrong (Ammerman:1976, 500); most probably no one was expecting a start with a civil war from a newly founded country. On the other hand, the consequences of French Revolution set a more tragic profile. Despite of the fact that according to an interpretation, French Revolution can be considered as a social movement due to the liberal demands and interests of bourgeoisie (Baker:1981, 281), without any doubt, again no one was expecting that bourgeoisie and the villager class shall be the primary target of the terror regime during the first decades of the revolution. Such that bourgeoisie, villager and working classes were forming 84 percent of the executions of the terror regime (Sander:2003, 166).In this context, this unpredictability and the random nature of international relations/affairs might be explained by the following terms: heterarchy and entropy.

In fact, hierarchy which is the opposite of heterarchy is a very famous and useful term for international relations. By a simple definition, hierarchy defines the subordination of various elements under the rule of a certain authority (Wang:2010, 516). In the context of 
international relations and politics, this term refers the state's classification based on their power ranking. Certainly, rationalism is considered as the main decisive element for this classification. Lastly, it has to be mentioned that by this power ranking classification, actors' movement ability can be estimated. On the other hand, as it is argued hither to, sometimes international actors' ability or the course of events can't be estimated correctly. In the previous paragraphs, this reality was considered synonymous of Murphy Laws effect on international relations. On the other hand, it is vital to find out the reasons of Murphy Laws in international relations.

According to Robert W. Cox, in spite of practical knowledge is more dominant against the abstractions and mystical revelations in international relations, even sometimes international relations theories comes short to perfectly identify certain cases such as the Arab Spring or Cold War (Cox:1981, 126-130). At this point, heterarchy notion can be more explanatory rather than the mystical approaches in international relations. As good as the other notions which are used in this study, heterarchy term is also a hybrid notion which feeds many different disciplines. When this term was firstly used by Warren McCulloch, he was investigating the emergence of reflexes which he defines a disturbance against the regular nervous path (McCulloch:1945, 89). In the following years, the term is also included to political science and international relations studies. In this context, sometimes in international relations certain types of activities don't stem simply from rank (Buzan:2014, 238). In other words, due to the unranked classifications of states, anything might happen within the international system in case of actors and international system are liken to a freefall within the space. Obviously, this argument challenges the so called hierarchical order in international systems which offers predictability for the policy makers. In the second place, it has to be mentioned that this approach is in the favor of relative subordinations instead of certain superordinations within the international system (White:1995,103); but what happens when the subordinations of politics become more dominant than the super-ordinations of international system?

\section{1-The Ultimate Secret Behind Assad's Survival: Entropy}

Every development gets exhausted and prepares its end...(Gündüz:2006, 347)

This prediction constructs the major argument of entropy which offers a very pessimistic approach for the universe. Despite of the fact that this term was firstly used in 1854 by the American physician Benjamin Thompson (Ibid., 347); shortly after the term has been popular in order to comprehend the failure of systems in social sciences. In the context of political science and international relations, entropy defines a chaos due to randomness (Schweller:2010, 145).In this sense, entropy emerges due Murphy Laws' hidden flows term within the system and these hidden flows might be explained also by the disorder and uniformity of energy, and once the entropy starts, it is believed that there is no "going back" (Ibid, 149). Because of this situation, yesterday's rule takers might become the tomorrow's rule makers (Schweller:2014, 1) and needless to mentioned that due to this uncertainty everything might stay in their own place.

In the case of the Arab Spring, it might be argued that except Assad, in all countries yesterday's rule takers has become the today's relatively rule makers. On the other hand, in Syrian case yesterday's rule maker is still the today's main rule maker. Moreover, despite of the fact that in all the Arab Spring affected countries, the "fear barrier" is now broken; (Harman:2012,2) on the other hand, the major instability in revolutionized countries and Assad's stand-alone resistance to the "wind of change" harms the legitimacy of the Arab 
Spring. Exactly at this point, another question might appear: "Can Assad be only taking the advantages of international anarchy in order to survive?" According to this study, the answer of this questions is "semi negative". It is partially true that Assad uses this anarchic environment for his strategic calculations in order to survive. In other words, anarchic environment in today's Syria warrants Assad to organize himself within the chaos. On the other hand, in spite of the fact that Alexander Wendt describes the anarchy as something what states make of it; (Wendt:1992, 395) this paper argues that random anarchy might only be the consequence of heterarchy and entropy. In the second place, this approach still can't give the satisfactory answer of the question that why only the Assad regime has survived within the completely anarchic environment of Middle East.

20 years ago, if someone would even imply the fall of military dictatorships in the Middle East, most probably for almost everyone this would be considered as a bad joke. Aftermath the revolutionist movements in Arab countries, if someone would estimate the survival of Assad regime in contrast to all the other dictatorships' fall, definitely the argument would be again unrealistic. On the other hand, today both of these possibilities are the truth itself. One more time the unexpected overcame the "ingenious" political expectations. In other words, the Murphy Laws are on duty in international relations.

\section{Conclusion}

Today the complexity of international relations forces the academics to think "beyond" the international relations theories. In particular, making certain distinctions between the theories zooms out the discipline to reach healthy analyzes. Because of this reason, both of the arguments of positivist and post-positivist approaches are adapted to this study in order to explain the Assad's survival from the Arab Spring.

Certainly, the Arab Spring is not only the greatest challenge to the "old order" in Middle East but also to the whole international system. Due to political scientists are not astrologers, it is very difficult to estimate the future of the Arab Spring whether it is the beginning of a new "French Revolution" or the failure will continue by getting worse. On the other hand, in the light of today's data, it seems that the Arab Spring couldn't meet the expectations for the following reasons. In the first place, the freedom and liberalism which were strongest expectations from this social movement didn't come true. In other words, the implementers of the old regimes had changed but the implementations remained the same. In the second place, Assad succeeded to maintain his power even in the terms of relativeness which can be considered as the greatest threat for the values of the Arab Spring. In the diplomatic history, many incidents or developments failed to meet the expectations by forcing the validity of international relations theories. It is possible to identify these systemic failures and error codes by using different perspectives. While some scholars describe this fact as the "will of God", other scholars intend to adapt the rules of life sciences in order to find the right answers. According to this paper, heterarchy and entropy come into prominence while defining the Murphy Laws of international relations. Certainly, one hand the nature of international relations is based on rationalism and pragmatic knowledge. On the other hand, it is also a fact that sometimes hierarchical system might turn into a very irregular structure where unranked actors randomly cause the fall of major developments or systems. As the final words, all these arguments entail us to the very beginning: Why Arab Spring is burning itself out?

"The probability of anything happening is in inverse ratio to its desirability." 


IN

\section{References}

Allison, R. (2013), "Russia and Syria: Explaining Allignment With A Regime in Crises", International Affairs, 89(4), p.795-823.

Ammerman, D. (1976), "The British Constitution and the American Revolution: A Failure of Precedent”, William\&Mary Law Review, 17(3), p.473-501.

Anonymous, "Murphy's Laws and Corollaries", http://bluebox.ippt.pan.pl/ vkoval/vk_files/funny/Murphy.pdf, (accessed 20.07.2018)

Baker, K.M. (1981), "Enlightenment and Revolution in France: Old Problems, Renewed Approaches", The Journal of Modern History, 53(2), p.281-303.

Bloch, A. (1978). Murphy Law and Other Reasons Why Things Go Wrong, USA: Price/Stern/Sloan Publications.

Buzan, B. (2014). "Brilliant But Now Wrong: A Sociological and Historical Sociological Assessment of Gilpin's Warand Change in World Politics", in John Ikenberry (ed.), Power, Orderand Change In World Politics, Cambridge: Cambridge University Press.

Chatterjee, A. (2015), “Is the Statement of Murphy’s Law Valid?”, https://arxiv.org/pdf/1508.07291.pdf\%3B, (accessed 21.10.2018)

Cox, W. R. (1981), "Social Forces, States and World Orders: Beyond International Relations Theory”, Millenium:Journal of International Studies, 10(2), p.126-155.

Çalış, Ş. ve Özlük, E. (2007), "Uluslararası İlişkiler Tarihinin Yapısökümü: İdealizm-Realizm Tartışması”, Selçuk Üniversitesi Sosyal Bilimler Enstitüsü Dergisi, 18, p. 225-243.

Donnelly, J. (2009) "Realizm," in Scott Burchill, et.al (ed.), Uluslararası İlişkiler Teorileri, (trans. Ali Aslan and Muhammed Ali Ağcan), İstanbul: Küre Yayınları, p.49-80.

Gündüz, M. (2006), “Sosyal Yaşam ve Entropi Yasası: Dünya’nın Sonuna Mı Yaklaştık?”, Atatürk Üniversitesi İktisadi ve İdari Bilimler Fakültesi Dergisi, 20(1), p. 345-355.

Harman, J. (2012), “Has theArab Spring Lived Up To Expectations?”, Viewpoints, 12, p.1-24.

Helfont, S. (2014), "Saddam and the Islamists: The Ba'thist Regime's Instrumentalization of Religion in ForeignAffairs", The Middle East Journal, 68 (3), p.352-366.

Holt, A. (1878). Review of the Progress of Steam Shipping During the Last Quarter of a Century, Britain:W.Clowes and Sons.

Khalifa, M.A. (2014), "Bahrain-Iran RelationsIn Modern Times", unpublished MA thesis, Monterey Naval Postgraduate School

Matthews, R. (1997), “The Science of Murphy's Law”, Scientific American, April, p.88-91.

McCulloch, W. (1945), “A Heterarchy of Values Determined by the Topology of Nervous Nets", Bulletin of Mathematical Biophysics, 7, p.89-93.

Mearsheimer, J. (2009), “Reckless States and Realism”, International Relations, 23(2), p. 241-256.

Mohammed, I. (2011), “Turkey and Iran Rivalry on Syria”, Alternatives: Turkish Journal of International Relations, 10(2-3), p.65-77.

Murphy, R. (2011). Murphy's Laws of Song Writing: TheBook, USA: Murphy Music ConsultingInc. 
Phillips, C. (2005), "Augustus de Morgan and the Propagation of Moral Mathematics", Stud. Hist. Phil. Sci., 36, p.105-133.

Rose, G. (1998), "Neoclassical Realism and Theories of International Relations", World Politics, 51, p.144-172.

Sander, O. (2003). Siyasi Tarih: İlkçağlardan 1918'e, Ankara: İmge.

Schulte, G. L. (2015), "Regime Change Without Military Force: Lessons from Overthrowing Milosevic", TheJournal of Complex Operations, 4(2), p.45-56.

Schweller, R. (2010), "Entropy and the Trajectory of World Politics: Why Polarity Has Become Less Meaningful?", Cambridge Review of of International Affairs, 23(1), p.145- 163.

Schweller, R. (2014), Maxwell's Demonandthe Golden Apple, Baltimore: John Hopkins University Press.

Spark, N.T (2011). A History of Murphy'sLaw, Los Angeles: Periscope Film.

Swaine, M. D. (2012), "Chinese Views of the Syrian Conflict", China Leadership Monitor, 39, p.1-18.

Ullman, H. K. (2014). A Handful of Bullets: How the Murder of Archduke Franz Ferdinand Still Menaces the Peace, (Annapolis: Naval InstitutePress.

Treitschke, H.V. (1914). German Destiny and Policies, New York: Knickerbocker Press.

Wang, F. (2010), "The Evolution of Hierarchy Toward Heterarchy: A Case Study On Baosteel's Managerial Systems", Frontiers of Business Research In China, 4(4), p.515-540.

White, J. (1995), "Incorporating Heterarchy intoTheory on Socio-Political Developmenet: The Case from Souteast Asia", American Anthropological Association, 6, p.101-123.

Wendt, A. (1993), “Anarchy is What States Make of it: The Social Construction of Power Politics”, International Organization, 46(2), p.391-425.

Winckler, O. (2013), “The Arab Spring: Socioeconomic Aspects”, Middle East Policy, 20(4), p.68-87.

Yalvaç, F. (2010), "Eleştirel Gerçekçilik: Uluslararası İlişkiler Kuramında Post-Pozitivizm Sonrası Aşama”, Uluslararası İlişkiler, 6(24), p.3-32.

Yetim, M. ve Erdağ, R. (2018), "Uluslararası İlişkilerde Eleştirel Söylem Analizi: Revizyonist Söylemin Gelişimi”, İstanbul Gelişim Üniversitesi Sosyal Bilimler Dergisi, 5(1), p.79-100. 